\title{
Free-ranging wild boar (Sus scrofa) in Switzerland: casual observations and model-based projections during open and closed season for hunting
}

\author{
Vargas Amado, M E ; Grütter, R ; Fischer, C ; Suter, S ; Bernstein, Abraham
}

\begin{abstract}
Free-ranging wild boar (Sus scrofa) in Switzerland: casual observations and model-based projections during open and closed season for hunting Wild boar (i.e., Sus scrofa) are susceptible to a range of diseases that can be transmitted to domestic pigs. Assessing the potential risk of transmission-related events involves identifying where wild boar occur in Switzerland and where they still can colonize. It also involves identifying zones where piggeries are dense. In the work presented here, the distribution of wild boar in Switzerland was projected from grid data as probabilities of presence using an approach based on statistical modeling, separately for closed and open season for hunting. The predicted probabilities of wild boar presence were related to the density of piggeries in the six agricultural zones. The resulting maps show how the potential risk of transmission-related events, as a proxy for disease transmission, is distributed in Switzerland. Wild boar presence data consisted of hunting data and casual observations recorded from September 2011 to February 2018 at the coordinate level. They were obtained from all 16 Swiss cantons maintaining a license hunting system plus Solothurn (for 2017) and Zurich, as well as from info fauna. The probability of wild boar occurrence was high (>0.7) in Jura, the valleys of the Southern Alps, the Rhone Valley down the river from Martigny, and the Rhine Valley down the river from Bündner Herrschaft; it was fair (0.5-0.7) in the Swiss Plateau. These regions broadly overlap agricultural zones with a high density of piggeries. Patches of perennially suitable, but currently not colonized habitat were found in the cantons of Berne, Obwalden, Uri, Schwyz, Glarus, and Grisons. The probability of wild boar occurrence across the entire study area, including the Alps, increased by $12 \%$ during closed season for hunting. The results were discussed with reference to similar studies.
\end{abstract}

DOI: https://doi.org/10.17236/sat00262

Posted at the Zurich Open Repository and Archive, University of Zurich

ZORA URL: https://doi.org/10.5167/uzh-197679

Journal Article

Published Version

Originally published at:

Vargas Amado, M E; Grütter, R; Fischer, C; Suter, S; Bernstein, Abraham (2020). Free-ranging wild boar (Sus scrofa) in Switzerland: casual observations and model-based projections during open and closed season for hunting. Schweizer Archiv für Tierheilkunde, 162(6):365-376.

DOI: https://doi.org/10.17236/sat00262 


\title{
Free-ranging wild boar (Sus scrofa) in Switzerland: casual observations and model-based projections during open and closed season for hunting
}

\author{
M.E. Vargas Amado1,2, R. Grütter ${ }^{1}$, C. Fischer ${ }^{3}$, S. Suter ${ }^{4}$, A. Bernstein² \\ ${ }^{1}$ Swiss Federal Research Institute WSL, Birmensdorf, Switzerland; ${ }^{2}$ Department of Informatics, University \\ of Zurich, Switzerland; ${ }^{3}$ Haute école du paysage, d'ingénierie et d'architecture HEPIA, Geneva, Switzerland; \\ ${ }^{4}$ ZHAW School of Life Sciences and Facility Management, Wädenswil, Switzerland
}

\begin{abstract}
Wild boar (i.e., Sus scrofa) are susceptible to a range of diseases that can be transmitted to domestic pigs. Assessing the potential risk of transmission-related events involves identifying where wild boar occur in Switzerland and where they still can colonize. It also involves identifying zones where piggeries are dense. In the work presented here, the distribution of wild boar in Switzerland was projected from grid data as probabilities of presence using an approach based on statistical modeling, separately for closed and open season for hunting. The predicted probabilities of wild boar presence were related to the density of piggeries in the six agricultural zones. The resulting maps show how the potential risk of transmission-related events, as a proxy for disease transmission, is distributed in Switzerland. Wild boar presence data consisted of hunting data and casual observations recorded from September 2011 to February 2018 at the coordinate level. They were obtained from all 16 Swiss cantons maintaining a license hunting system plus Solothurn (for 2017) and Zurich, as well as from info fauna. The probability of wild boar occurrence was high $(>0.7)$ in Jura, the valleys of the Southern Alps, the Rhone Valley down the river from Martigny, and the Rhine Valley down the river from Bündner Herrschaft; it was fair (0.5-0.7) in the Swiss Plateau. These regions broadly overlap agricultural zones with a high density of piggeries. Patches of perennially suitable, but currently not colonized habitat were found in the cantons of Berne, Obwalden, Uri, Schwyz, Glarus, and Grisons. The probability of wild boar occurrence across the entire study area, including the Alps, increased by $12 \%$ during closed season for hunting. The results were discussed with reference to similar studies.
\end{abstract}

Keywords: Colonization, habitat suitability, risk assessment, spatial projection, species distribution, Sus scrofa
Wildschweine (Sus scrofa) in der Schweiz: Beobachtungen und modellbasierte Projektionen während der Jagd- und Schonzeit

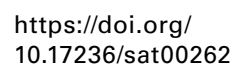
$10.17236 /$ sat00262

Received: 25.08.2019 Accepted: 09.04.2020
Eine Reihe von Krankheiten, für welche das Wildschwein (Sus scrofa) empfänglich ist, können auf das Hausschwein übertragen werden. Zur Abschätzung des potenziellen Risikos von übertragungsrelevanten Ereignissen muss herausgefunden werden, wo das Wildschwein in der Schweiz vorkommt und welche Gebiete es noch besiedeln kann. Ebenso müssen Zonen mit einer hohen Dichte von Schweinehaltungen bestimmt werden. In der vorliegenden Arbeit wurde das beobachtete Wildschweinvorkommen während der Jagdsaison und in der Schonzeit als Auftretenswahrscheinlichkeiten in ein landesweites Datenraster projiziert. Das so vorhergesagte Auftreten wurde zur Anzahl an Schweinebetrieben pro Quadratkilometer in Beziehung gesetzt. Die resultierenden Karten zeigen, wie das potenzielle Risiko von übertragungsrelevanten Ereignissen, stellvertretend für eine Krankheitsübertragung, in der Schweiz verteilt ist. Die Datenbasis bestand aus Jagddaten und beiläufigen Beobachtungen, soweit diese zwischen September 2011 und Februar 2018 koordinatengenau aufgezeichnet wurden. Sie wurden von allen 16 Patentjagdkantonen, plus Solothurn (2017) und Zürich, sowie von info fauna für die Studie bereitgestellt. Im Jura, in den Alpensüdtälern, im Rhônetal unterhalb von Martigny und im Rheintal unterhalb der Bündner Herrschaft war die Wahrscheinlichkeit des Wildschweinvorkommens hoch (>0.7); im Mittelland war die Wahrscheinlichkeit mittel bis hoch (0.5-0.7). Diese Regionen decken sich weitgehend mit Zonen mit einer hohen Schweinebetriebsdichte. Ganzjährig für das Wildschwein geeigneter, aber noch unbesiedelter Lebensraum wurde in den Kantonen Bern, Obwalden, Uri, Schwyz, Glarus und Graubünden 
Free-ranging wild boar (Sus scrofa) in Switzerland: casual observations and model-based projections during open and closed season for hunting

M.E. Vargas Amado et al. gefunden. Schweizweit erhöhte sich die Auftretenswahrscheinlichkeit in der Schonzeit um 12\%. Die Resultate wurden unter Bezugnahme auf ähnliche Studien im In- und Ausland diskutiert.

Besiedlung, Lebensraumeignung, Risikobewertung, räumliche Projektion, Artenverteilung, Sus scrofa

\section{Introduction}

Wild boar are susceptible to a range of diseases that can affect also domestic pigs. Examples are Enzootic Pneumonia (EP) and African swine fever (ASF). ${ }^{6,12}$ ASF is currently spreading in European wild boar populations, though Switzerland is still free from the disease. ASF can be transmitted to domestic pigs via contact with infected animals, or contaminated carcass remains and equipment. ${ }^{12}$ It has a high mortality rate and is a major threat for the pig industry, particularly in Switzerland where the proportion of outdoor piggeries is high. Identifying the spots where a direct or indirect contact between wild boar and domestic pigs can take place is critical to develop risk-based surveillance systems for improving early disease detection and control. This involves, identifying where wild boar occur in Switzerland and where they still can colonize. It also involves identifying zones where piggeries are dense.

The abundance and density of wild boar in Switzerland has already been investigated in related work. The probability of wild boar occurrence per hunting area and $s q k m$ was predicted using a set of landscape composition

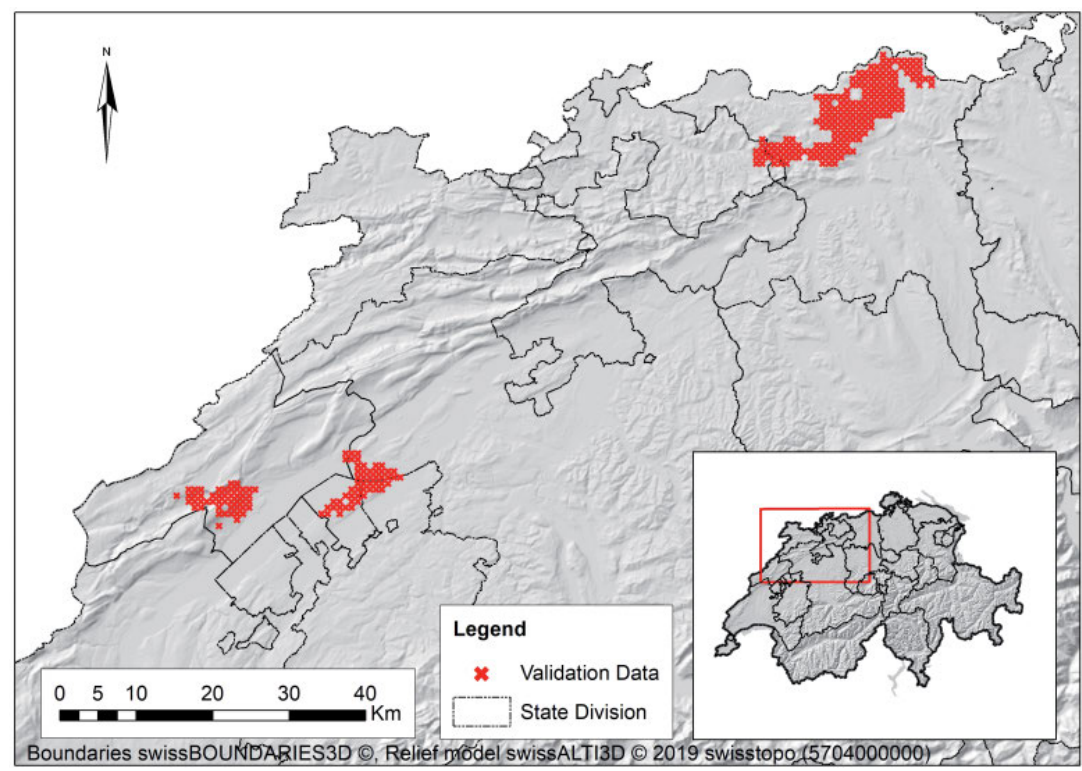

Figure 1: Areas in the cantons of Neuchâtel, Vaud, Fribourg, Berne, Basel-Country, and Aargau where the wild boar (Sus scrofa) presence data used for external validation of the summer and winter model have been collected. variables and the annual hunting statistics per hunting area as a surrogate of population data. ${ }^{31}$ Wild boar abundance and density were also estimated based on capture-resights in the canton of Geneva. ${ }^{28}$ The spatial overlap between areas roamed by free-ranging wild boar and outdoor piggeries was mapped at the level of municipalities. ${ }^{59}$ Information on wild boar, in that study, originated from qualitative reports to the Centre Suisse de Cartographie de la Faune (CSCF) and from a questionnaire survey among pig farmers. ${ }^{60}$ Lately, wild boar occurring in Switzerland were mapped by density class as an aggregate of wild boar hunted or found dead in municipalities or hunting grounds. ${ }^{34,35}$ The distribution and abundance of wild boar has been mapped also in Europe and Eurasia, including Switzerland, in terms of rasters of $10 \mathrm{~km}, 5 \mathrm{~km}$ and, as of recently, $2 \mathrm{~km}$ based on very heterogeneous data from various sources. $3,46,1,16$

The work presented here extends beyond the above cited by cumulatively satisfying the requirements listed below. The distribution of wild boar (i.e., Sus scrofa) in Switzerland was projected

- From grid data as probabilities of presence using an approach based on statistical modeling (an approach based on statistical modeling was also taken in other studies);31,3,46,1,16

- with a fine-grained spatial resolution of $1 \mathrm{sq} \mathrm{km}$ (a raster map of $1 \mathrm{sq} \mathrm{km}$ was also produced in other work, albeit unpublished); ${ }^{31}$

- separately for summer (closed season for hunting) and winter (open season for hunting). Summer (MarchAugust) and winter (September-February) were distinguished in accordance with the hunting season rather than with vernal and autumnal equinoxes. In the hunting season, there are more carcasses available (i.e., wild boar shot but not retrieved). Since the species is to some extent scavenging on carcasses and, in the case of ASF, the virus survives well in them, the risk of being infected is then increased. ${ }^{12}$

The approach adopted here to project the occurrence of wild boar in Switzerland reflects the state-of-the-art of species distribution modeling (SDM) in conservation biology and ecology. ${ }^{25}$ Thereby, the term 'projection' refers to a model-based spatial prediction in a data grid. Statistical models were fitted and evaluated in an initial dataset of wild boar presences and (pseudo-) absences. 
They were then used to predict the probabilities of presence in the entire study area, namely, all of Switzerland. The predicted probabilities of wild boar presence for the two seasons were related to the density of piggeries in the six agricultural zones. The resulting maps show how the potential risk of transmission-related events, as a proxy for disease transmission, is distributed in Switzerland.

\section{Material and methods}

\section{Study area}

The study considers all of Switzerland. Switzerland is located in Western and Central Europe and covers a total surface area of 41,285 $\mathrm{sq} \mathrm{km}$ ranging from 193 to 4,634 meters above sea level. It has three main geographic regions: the Alps, covering around $60 \%$ of the country's total surface area, the Swiss Plateau (30\%) and the Jura (10\%). Of Switzerland's surface area, $7.5 \%$ is used for settlements and urban areas, trade, industry and transport, energy supply and waste disposal or recreational areas and parks, while agricultural land occupies $35.9 \%$, and forests as well as woodlands $31.3 \% .54$

The Alps act as a prominent climatic barrier between Northern and Southern Switzerland. The climate of Northern Switzerland is heavily influenced by the Atlantic Ocean. Winters in the Northern Plateau are mild and damp, whereas higher altitudes experience arctic temperatures. At altitudes above 1,200-1,500 meters, precipitation in winter mainly falls as snow. Southern Switzerland is strongly affected by the Mediterranean Sea, and so winters are mild and summers warm and humid, and sometimes hot. All along the Alpine ridge there are frequent thunderstorms in the summer. ${ }^{55}$

\section{Species data}

Wild boar presence data consisted of 12,693 hunting data and 11,430 casual observations recorded from September 2011 to February 2018 at the coordinate level. They were obtained from all 16 Swiss cantons maintaining a license hunting system, covering roughly two thirds of the overall area, plus Solothurn (for 2017) and Zurich, as well as info fauna (copyright by the data providers). A short description of license hunting and a map showing all cantons implementing this system can be looked up on the web site of Eidgenössische Jagdstatistik. In order to account for the inaccuracy of locating observations, all data were aggregated to a $1 \mathrm{sq} \mathrm{km}$ grid. Doing so resulted in 1,702 data cells with reported wild boar presence in summer and 2,882 data cells with reported wild boar presence in winter. Info fauna records observational data on a $b a$ basis of which, according to them, only $+/-20 \%$ were correctly located by the observers. They recommended to use the $s q \mathrm{~km}$ data which are sufficiently precise.

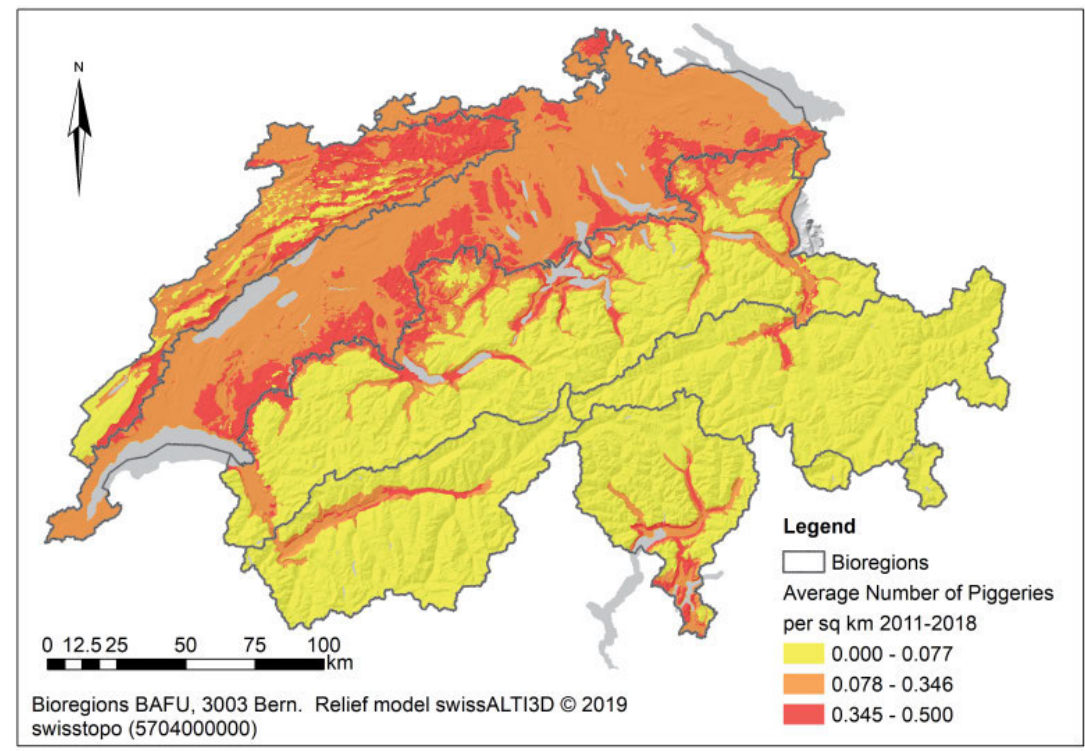

Figure 2: Piggeries per sq $k m$ in Switzerland, averaged across 2011-2018. Data source: Landwirtschaftliche Zonengrenzen der Schweiz, Bundesbehörden der Schweizerischen Eidgenossenschaft.

For each season, pseudo-absences were collected by sampling a number of data cells, equal to that of presence data, at random from the $1 \mathrm{sq} \mathrm{km}$ grid of Switzerland. Samples that are unbalanced with respect to presences/ pseudo-absences have been demonstrated to reduce the accuracy of the models. ${ }^{25}$ When sampling at random, (1) the sites of recorded presences and (2) waters and glaciers were not considered. The former were omitted in order not to introduce noise into the data by sampling pseudo-absences from presence data. The latter were omitted in order to constrain the study area to a realistic realm by factoring out areas that are from the outset unsuitable. ${ }^{25}$ Areas above 2,000 meters above sea level (which corresponds roughly to the tree line), where wild boar occur only sporadically, were sampled twice as densely. ${ }^{31,34}$ The intention was to outweigh the initial bias in the presence data towards environmental conditions in easily accessible areas below 2,000 meters. ${ }^{45}$ Figure 3 and 4 (top) show the locations of the presence data cells for summer and winter.

For external validation the presence records from a published and an unpublished study were used (cf. Figure 1). In the former, data came from GPS-collared wild boar, recorded from 2014 to 2017 in the cantons of Vaud, Fribourg, Berne, Basel-Country, and Aargau. ${ }^{52}$ In the latter study, occurrence data were recorded based on capture-resights from 2011 to 2014 in the canton of Neuchâtel. Together presence data were recorded in 160 grid cells in each season.

\section{Predictor variables}

Twenty-six predictor variables were manually pre-selected using the current ecological understanding of the 
Free-ranging wild boar (Sus scrofa) in Switzerland: casual observations and model-based projections during open and closed season for hunting

M. E. Vargas Amado et al. Inventory (NFI), and the forest mask NFI. The sources of the predictor variables are listed in the Appendix. For each seasonal variable, namely each bioclimatic variable and two vegetation variables, two raster maps were produced, one for summer (March-August), another for winter (September-February), using average values

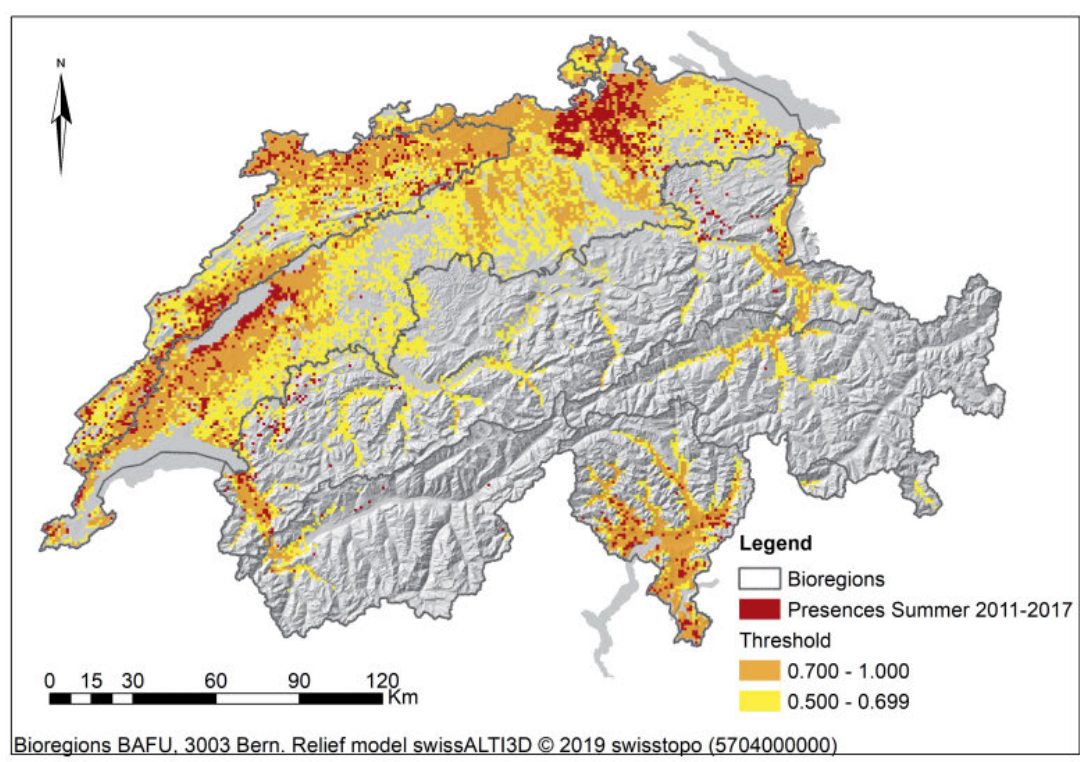

3003 Bern. Relief model swissALTI3D

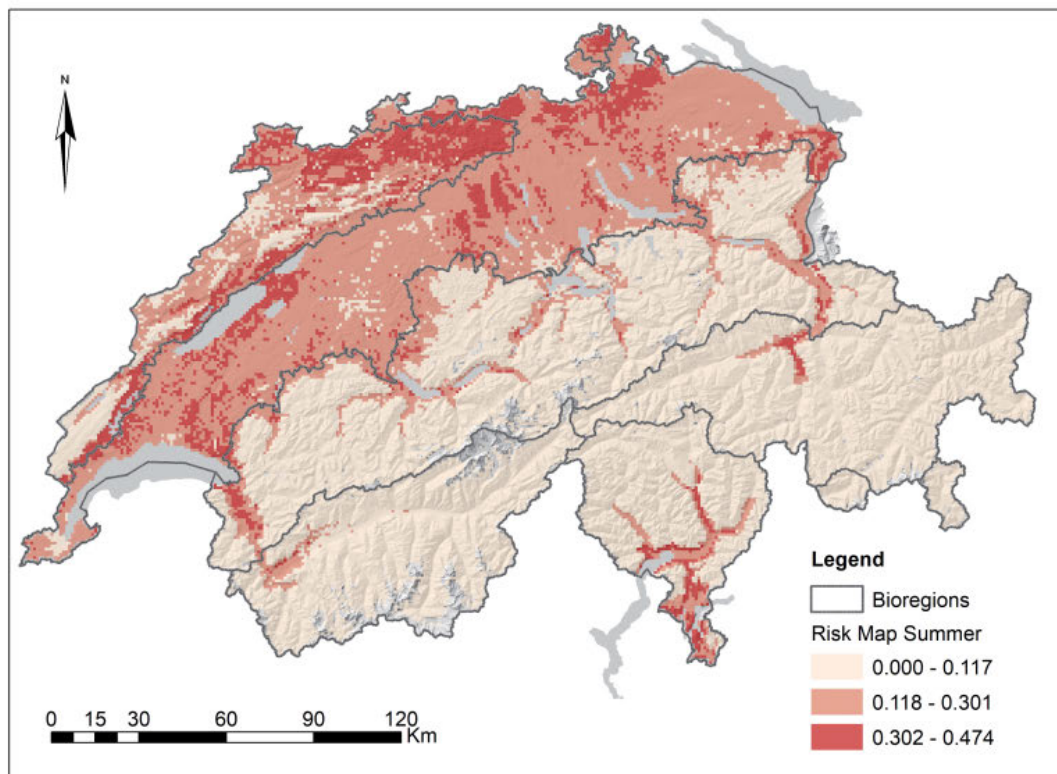

Bioregions BAFU, 3003 Bern. Relief model swissALTI3D @ 2019 swisstopo (5704000000)

Figure 3: Top Projected Sus scrofa occurrence with probabilities of $0.5-0.7$ and $>0.7$, and actual observations (summer). Bottom Potential risk of transmission-related events in summer calculated as wild boar probability $\times$ piggery/sq $\mathrm{km}$. across 2011/12-2017/18. For all other variables, a single raster map was produced. All raster maps had the same spatial resolution, namely, $1 \mathrm{sq} \mathrm{km}$, which fitted with the uncertainty of the position coordinates for the point observations (cf. section Species data). They had the same lower-left coordinate and the same spatial extent, namely, all of Switzerland.

The final variables were identified in a repeated (20 times) 5 -fold cross-validation procedure as explained below. ${ }^{10}$ For each repetition the variables were selected in a stepwise backward elimination process carried out by growing at each step 1,000 trees with at least 20 terminal nodes using the random forest algorithm. ${ }^{9}$ The predictive accuracy of the selected variables was estimated by joining the predictions of the 5 cross-validation subsets and computing the area under the Receiver Operating Characteristic (ROC) curve. ${ }^{48,53}$ The set of variables maximizing the AUC was returned, and strongly correlated variables $(|r|>0.7)$ with a low mean decrease in the Gini coefficient were removed.22,23 The R packages used for variable selection are listed in the Appendix. Random forests are built from multiple regression trees, which classify data by clustering rather than by linear separation. Accordingly, they do not assume that the values of the predictor variables and those of the response variable have a linear relationship. ${ }^{21}$ Being non-parametric models, they further do not assume independence and, hence, are not affected by spatial-autocorrelation, unless sampling is biased from the source to target scale. ${ }^{17}$ The latter was demonstrated in a simulation experiment with gridded data. ${ }^{50}$ The predictor variables selected by this procedure for summer and winter are shown in Table 1.

\section{Modeling}

An ensemble approach was adopted to model the potential distribution of wild boar in Switzerland. ${ }^{25}$ For each season, the ensemble consisted of two regression-based approaches, one classification approach, and two approaches based on machine learning: generalized additive model (GAM) with default settings; multivariate adaptive regression splines (MARS) without interaction terms; flexible discriminant analysis (FDA) using MARS as the fitting method; random forest (RF), parameterized to grow 1,000 trees; and support vector machine (SVM) with default settings. ${ }^{27,19,26,14,9}$ These five approaches outperformed in a pre-test (not shown) the generalized linear model (GLM) with a binomial distribution and a logit link function, artificial neural networks (ANN) using a cross-validation procedure to select the optimal size of the hidden layer and weight decay, and Naive Bayes with priors of 0.5 for presence and absence. ${ }^{33,32,43}$ The $\mathrm{R}$ packages used for ensemble modeling are listed in the Appendix. The five approaches were ensembled as (continuous) joint probability distributions and discretized 
maps (presences at two different levels of probability) to serve researchers and decision makers alike. The ensemble predictions were obtained by calculating a weighted average of the predictions from all models, according to the formula:

$$
\bar{p}=\sum_{i=1}^{n}\left(w_{i} \times p_{i}\right)
$$

where $w_{i} \times p_{i}$ was the predicted probability from model $i$, weighted by its weight of evidence, and $n$ the number of models considered. The weights were obtained by repeatedly (100 times) running a balanced (i.e., equal numbers of presence and pseudo-absence cells) split-sample cross-validation (80\% training, 20\% testing) and computing the areas under the ROC curves. Accordingly, models showing a good predictive performance were upweighted in the averaged prediction. Discretized maps were produced using the following classifier:

Sus scrofa is $\left\{\begin{array}{l}\text { likely present } \quad \text { if } \quad \bar{p} \geq 0.7 \\ \text { potentially present if } 0.5 \leq \bar{p}<0.7\end{array}\right.$

The value of 0.7 used as a threshold for likely presence is in line with current practice. ${ }^{4,49} \mathrm{~A}$ value of 0.5 used as a threshold for potential presence is also used occasionally. ${ }^{20}$

\section{Evaluation}

Model predictions were validated in the gridded presence data and in independent data (cf. section Species data). When fitting the habitat suitability models, the residuals were tested for spatial autocorrelation to identify the amount of spatial structure in the species data that was not explained by the predictors. ${ }^{25}$ To this end, global Moran's I was computed for summer GAM and winter GAM. ${ }^{39}$ This involved deriving a distance matrix from all observations, and testing the distance effect against the residuals. ${ }^{25}$

\section{Limitations of the modeling approach}

The literature discusses a number of theoretical and methodological assumptions that a species distribution model should meet. ${ }^{25}$ However, meeting all assumptions is rarely feasible, and assumptions that are not fully met reflect the limitations of the model. The most relevant for the study presented here are (1) limited availability of presence data, (2) possibly biased presence data, and (3) possibly spatially correlated observations.

In a widely cited study some support for a minimum sample size in multiple regression (two of the approaches adopted here are regression-based) of $n=50+8 \times m$ was obtained with $m$ the number of predictor variables. ${ }^{24}$ This number increases with the number of categories if categorical variables are used. Thus, in the study presented here the minimum sample size is $50+8 \times(12+4)=178$. This number is clearly outmatched by the 1,702 data cells with reported wild boar presence in summer and the 2,882 data cells in winter. However, more important than the absolute number of observations is the extent to which these cover the whole range of environmental conditions suitable for a species, which is discussed in the next paragraph.

Presence data are often biased towards easily accessible areas. ${ }^{45}$ When delivering the data, info fauna made clear that their data are biased towards areas usually visited by observers (e.g., ornithologists) and towards sightings in the open field. Hunting data, on the other hand, are

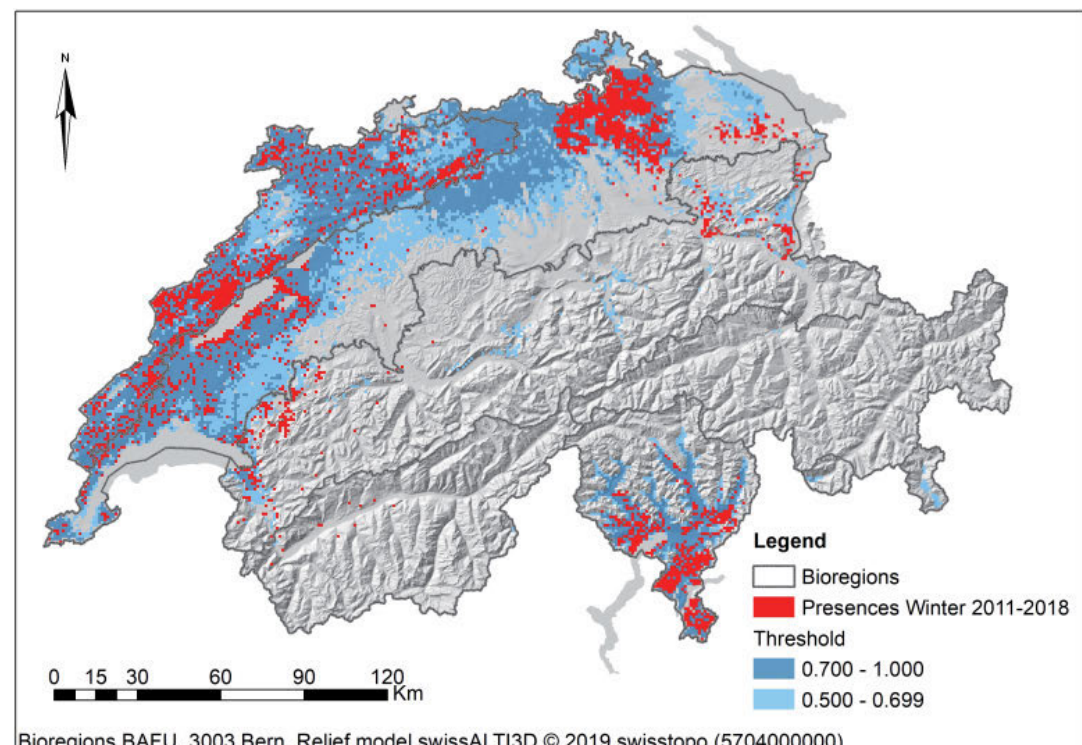

Bioregions BAFU, 3003 Bern. Relief model swissALTI3D @ 2019 swisstopo (5704000000)

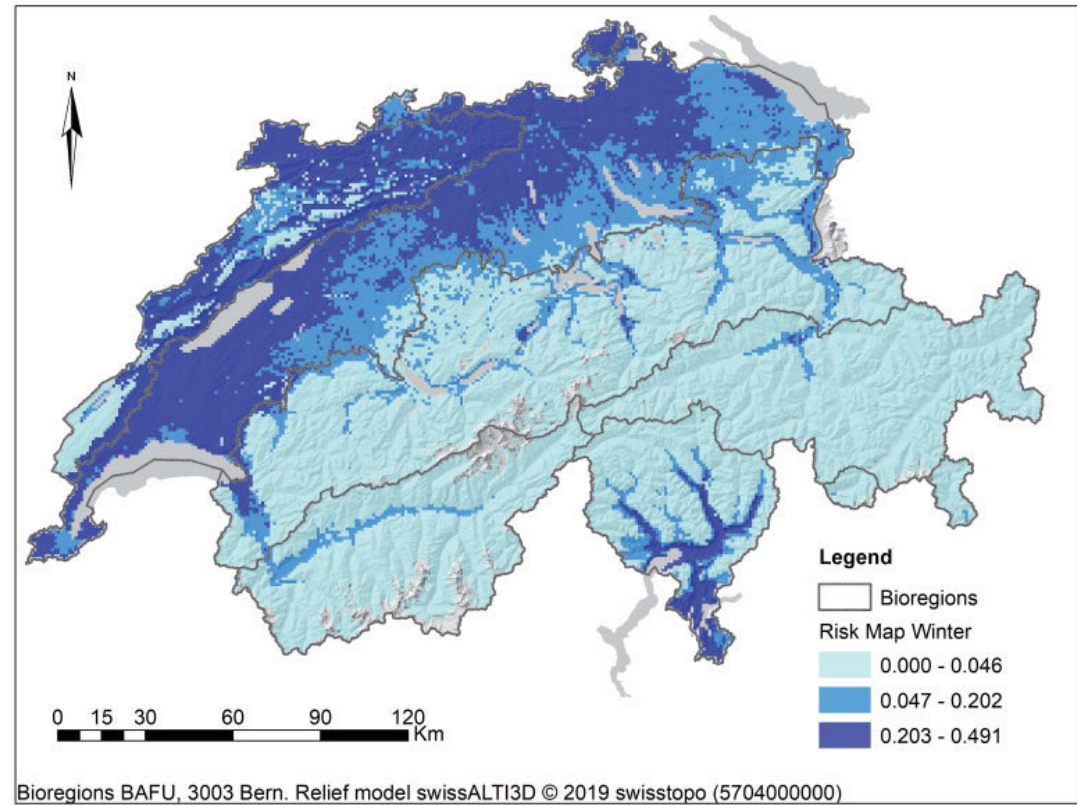

Figure 4: Top Projected Sus scrofa occurrence with probabilities of $0.5-0.7$ and $>0.7$, and actual observations (winter). Bottom Potential risk of transmission-related events in winter calculated as wild boar probability $\times$ piggery $/ \mathrm{sq} \mathrm{km}$.
Free-ranging wild boar

(Sus scrofa) in

Switzerland: casua model-based projections during open and closed season for hunting

M.E. Vargas Amado et al. 
Table 1: Predictor variables selected for statistical modeling in a stepwise backward elimination process using random forest in summer and winter. $\mathrm{n} / \mathrm{a}=$ variable not selected for this season. Predictor variables: Bioclimatic (Bio 1-Bio 15, SrelM), topographic (s/p), vegetation (ddeg0), land use (NOAS04), (human) population density (STATPOP).

\begin{tabular}{l|l|c|c|c} 
Variable & \multicolumn{1}{|c|}{ Definition } & Unit & MDGS & MDGW \\
\hline Bio 1 & Semi-annual mean temperature & ${ }^{\circ} \mathrm{C}$ & 144.299 & $\mathrm{n} / \mathrm{a}$ \\
\hline Bio 2 & Semi-annual mean diurnal range & ${ }^{\circ} \mathrm{C}$ & $\mathrm{n} / \mathrm{a}$ & 51.432 \\
\hline Bio 4 & Temperature seasonality & ${ }^{\circ} \mathrm{C}$ & 43.416 & 83.162 \\
\hline Bio 7 & Semi-annual temperature range & ${ }^{\circ} \mathrm{C}$ & 37.170 & $\mathrm{n} / \mathrm{a}$ \\
\hline Bio 13 & Precipitation of wettest month & $\mathrm{mm}$ & $\mathrm{n} / \mathrm{a}$ & 87.894 \\
\hline Bio 14 & Precipitation of driest month & $\mathrm{mm}$ & 43.208 & 82.515 \\
\hline Bio 15 & Precipitation seasonality & $\%$ & 58.285 & 164.472 \\
\hline ddeg0 & Growing degree days above $0^{\circ} \mathrm{C}$ & ${ }^{\circ} \mathrm{C}$ days & $\mathrm{n} / \mathrm{a}$ & 232.448 \\
\hline SrelM & Rel. sunshine duration & $\%$ & 45.461 & 134.011 \\
\hline slp & Rate of change of elevation & deg & 30.400 & $\mathrm{n} / \mathrm{a}$ \\
\hline NOAS04 & Land use & $4 \mathrm{classes}$ & $\mathrm{n} / \mathrm{a}$ & 41.454 \\
\hline STATPOP & Population density & $\mathrm{n} / \mathrm{ha}$ & 31.543 & 37.335 \\
\hline
\end{tabular}

MDGS, mean decrease in Gini coeffcient (summer); MDGW, mean decrease in Gini coeffcient (winter)

Table 2: Internal validation: True Positive Rates (= rates of presence data cells from this study that were correctly predicted) for summer and winter.

\begin{tabular}{l|c|c|c|c} 
Season & Threshold & Sample size & True positives & TPR \\
\hline \multirow{2}{*}{ Summer } & 0.7 & 1,677 & 1,280 & $0.742-0.783$ \\
\cline { 2 - 5 } & 0.5 & 1,677 & 1,555 & $0.914-0.939$ \\
\hline \multirow{2}{*}{ Winter } & 0.7 & 2,831 & 2,324 & $0.806-0.835$ \\
\cline { 2 - 5 } & 0.5 & 2,831 & 2,619 & $0.915-0.934$ \\
\hline
\end{tabular}

TPR, True Positive Rate

Table 3: External validation: True Positive Rates (= rates of presence data cells from two independent studies that were correctly predicted) for summer and winter. Data came from GPS-collared wild boar, recorded 2014-2017 in the cantons of Vaud, Fribourg, Berne, Basel-Country, Aargau, and from capture-resights, recorded 2011-2014 in the canton of Neuchâtel.

\begin{tabular}{l|c|c|c|c} 
Season & Threshold & Sample size & True positives & TPR \\
\hline \multirow{2}{*}{ Summer } & 0.7 & 160 & 153 & $0.912-0.982$ \\
\cline { 2 - 5 } & 0.5 & 160 & 152 & $0.904-0.978$ \\
\hline \multirow{2}{*}{ Winter } & 0.7 & 160 & 160 & $0.977-1.000$ \\
\cline { 2 - 5 } & 0.5 & 160 & 160 & $0.977-1.000$ \\
\hline
\end{tabular}

TPR, True Positive Rate

biased towards the woods where the battues are carried out. The problem with biased observations is that the environmental conditions in suitable areas that are difficult to access are underrepresented or, in the worst case, not represented at all. The work presented here dealt with a possible bias in the presence data by sampling psedo-absences in potentially unsuitable areas twice as densely as in potentially suitable ones. Doing so resulted in better predictions when compared to sampling pseudo-absences regularly across the study area (not shown). However, as the true positive rates for a threshold of 0.7 in Table 2 suggest, the projections still tend to underpredict the occurrence of wild boar in Switzerland.
Species data are almost always spatially autocorrelated. ${ }^{25}$ Spatial autocorrelation may occur if species presences are taken from samples in overly close proximity. When species data are autocorrelated the degrees of freedom used in many statistics associated with the models no longer correspond to the number of observations. ${ }^{30}$ As a result, some statistics may be inaccurate or even wrong. ${ }^{15}$ In the study presented here observations in $b a$ were aggregated to presences in $s q \mathrm{~km}$. In this way not only the imprecision in the original data was accounted for, but also were species data thinned, in some areas almost hundredfold. As Figure 6 shows, there is still some weak spatial correlation $(<0.4)$ in the residuals, particularly at short distances and in winter. An attempt to further thin the data using the respective toolset in a geographic information system did not decrease the correlation in the residuals (not shown). This may point to the presence of ecological or environmental processes that are not fully captured by the predictor variables. ${ }^{25}$

\section{Results}

\section{Modeling}

Figure 3 and 4 (top) show the discretized maps for summer and winter, overlayed by the presence data used for modeling (cf. section Species data) and the six biogeographical regions in Switzerland. These regions subdivide the three geographic regions mentioned in section Study area into smaller ones based on their faunistic and floristic potential. It is worth noting that in Valais wild boar has since been observed also in Lötschental, Mattertal, Gantertal, and Goms, according to info fauna.

In both seasons, the probability of wild boar occurrence is high $(>0.7)$ in Jura, the valleys of the Southern Alps, the Rhone Valley down the river from Martigny, and the Rhine Valley down the river from Bündner Herrschaft. In summer it is also high in the upper Rhine valley. The probability is fair $(0.5-0.7)$ in the Plateau and, particularly in summer, in the valleys of the Northern Alps.

The true positive rates (TPRs), computed as Clopper-Pearson confidence intervals at a level of $95 \%$, are shown in Table $2 .{ }^{13}$ The probability of wild boar occurrence across the entire study area, including the Alps, increased by $12 \%$ in summer when compared with winter. Figure 3 and 4 (bottom) show the potential risk of transmission-related events, calculated as wild boar probability $\times$ piggery / sq km, for both seasons in Switzerland. It is important to see, that this potential cannot be fully realized because of a number of natural and artificial barriers, the effects of which are discussed in Section Discussion. 
Figure 5 shows patches of perennially suitable habitat in the cantons of Berne, Obwalden, Uri, Schwyz, Glarus, and Grisons that are currently not colonized. For the rest of Switzerland, the joint probability distributions were similar to the discretized maps shown in Figure 3 and 4 (top). It is worth noting that a high probability of occurrence does not necessarily indicate a high density of wild boar. A more detailed analysis should be based on the estimated density of wild boar, which is outside the scope of this article.

\section{Evaluation}

The values of the areas under the ROC curves (AUC), averaged across 100 split-sample cross-validation runs for summer and winter (cf. section Modeling), are shown below. These values were the weights used to compute the joint probability distributions from the predictions of the individual approaches in the ensemble.

$\begin{array}{rrrrrrr} & \text { GAM } & \text { MARS } & \text { FDA } & \text { RF } & \text { SVM } \\ \text { AUC_Summer } & 0.872 & 0.860 & 0.861 & 0.919 & 0.883 \\ \text { AUC_Winter } & 0.898 & 0.884 & 0.883 & 0.937 & 0.891\end{array}$

The results of the validation in the external dataset (cf. section Species data) are shown in Table 3. The tests for spatial autocorrelation in the residuals of the GAM model revealed significant, but weak positive relationships, particularly at short distances and in winter, thereby implying that the major part of the spatial structure in the species data was explained by the predictor variables (cf. Figure 6).

\section{Discussion}

The risk maps in Figure 3 and 4 (bottom) show for both seasons patterns similar to the density of piggeries in Figure 2. The reason is that there is a broad overlap between piggeries and areas where wild boar are potentially or likely present (cf. Figure 3 and 4, top). Accordingly, the potential risk of transmission-related events is currently highest in Jura, the Swiss Plateau, the Rhône valley, the valleys of the Southern Alps, and the Rhine valley. Transmission-related events refer to a range of conditions that encourage the transmission of diseases, such as ASF, from wild boar to domestic pigs. Examples are a direct contact with infected animals in outdoor piggeries, an indirect contact via contaminated clothes or equipment, or using straw from cropland ranged by wild boar as litter in piggeries. ${ }^{12}$ Indirect contacts are more likely where farmers are themselves hunters or welcome hunters on their farm, and where farmers and hunters have access to dead animal disposal plants on the same weekday. Not only are wild boar likely to occur where piggeries are dense, but also where the human population is dense (cf. STATPOP in Table 1). This supports the hypothesis that wild boar are a synanthropic species. ${ }^{42}$

The joint probability distributions suggest that the (re-) colonization of Switzerland by wild boar from France, Germany, and Italy is not yet completed. Particularly, in the cantons of Berne, Obwalden, Uri, Schwyz, Glarus, and Grisons the models predict perennially some suitable habitat that is currently not populated. In Obwalden, Uri, Schwyz, and Glarus none or only a few animals were observed or shot in years 2009 through

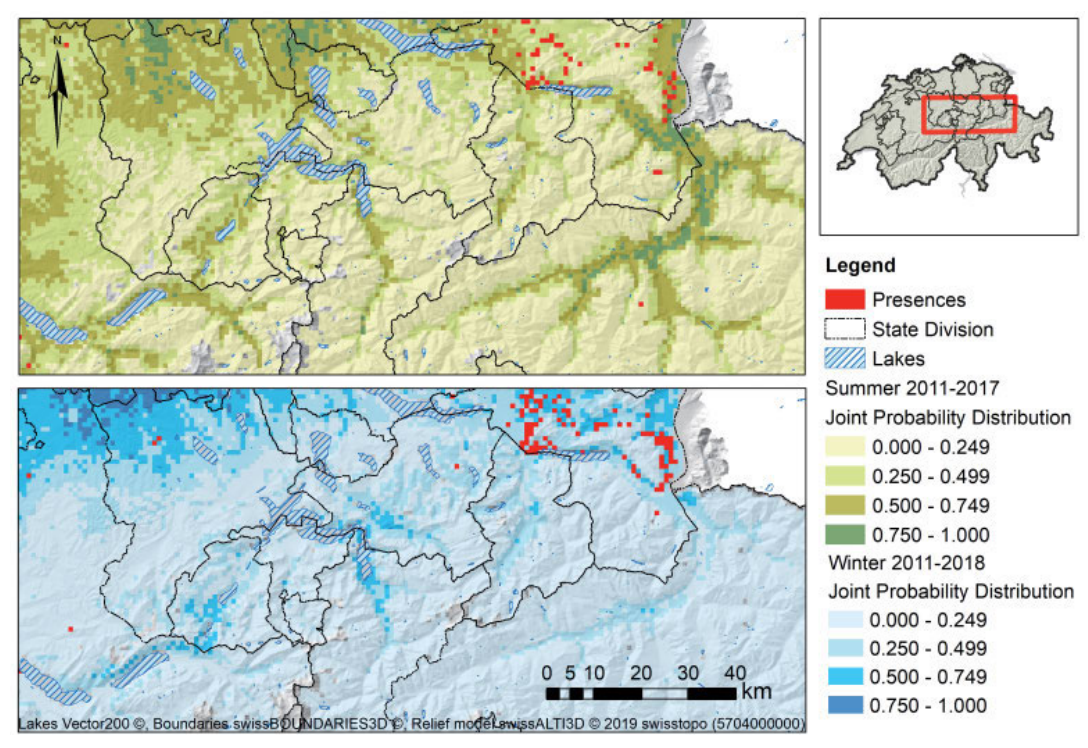

Figure 5: Joint probability distribution of Sus scrofa showing patches of perennially suitable, but currently not colonized habitat in the cantons of Berne, Obwalden, Uri, Schwyz, Glarus, and Grisons.

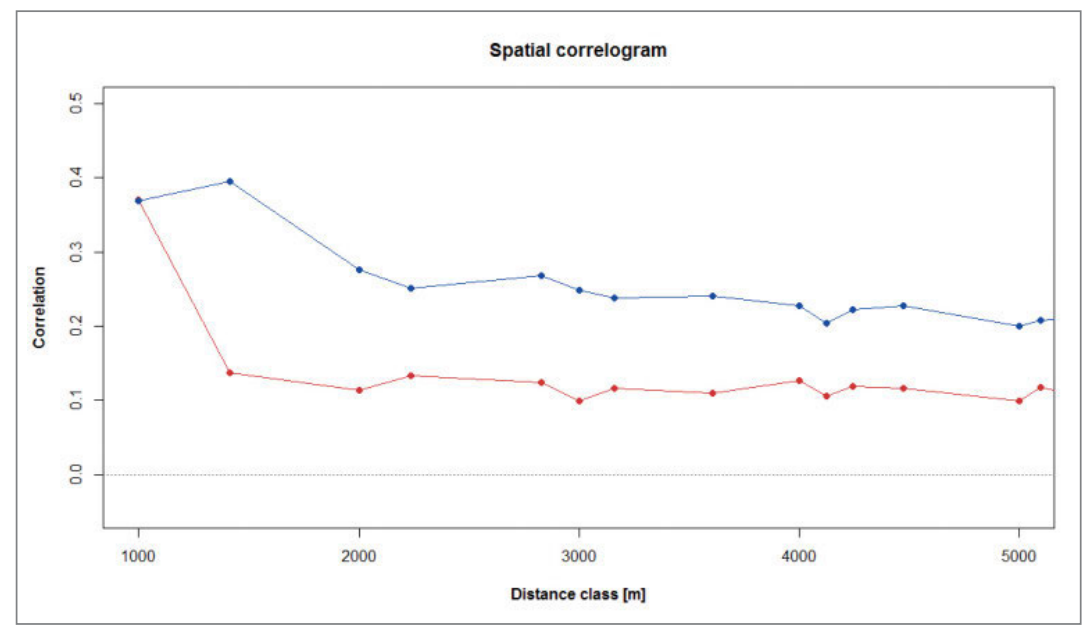

Figure 6: Spatial correlation of model residuals at increasing distances between sample locations in summer (red) and winter (blue) using the predictor variables in Table 1. It shows some significant, but weak positive relationships, particularly at short distances and in winter. 
Free-ranging wild boar (Sus scrofa) in Switzerland: casual observations and model-based projections during open and closed season for hunting

M.E. Vargas Amado et al. Gall. The projections suggest that they are likely to colonize the (anterior) Rhine valley (and side valleys) of Grisons unless gamekeeping prevents them from doing so. In the future wild boar may benefit from climate change, range in even higher altitudes in summer, and overwinter in the Prealps.

A study on surveilled wildlife passages at the junction between the Jura and the Swiss Plateau as well as in the Swiss Plateau identified highway A5 at the south foot of Jura between Yverdon-les-Bains and Luterbach as a potential barrier for wild boar ${ }^{59}$. The spatial distribution of presence records in the study presented here suggests that this barrier has since been overcome in the Neuchâtel area and wild boar on march got stuck at highway A10 between Neuchâtel and Kerzers, and highway A1 between Kerzers and Berne (cf. Figure 7). The projections in Figure 5 suggest that, without these barriers, wild boar would colonize areas along the Aare river, Lake Thun, Lake Brienz, in the Hasli valley and the other valleys of the Bernese Oberland to the extent that these are predominantly covered with deciduous forest. These are areas where piggeries are dense (cf. Figure 2) and where the risk of transmission-related events is high (cf. Figure 3 and 4, bottom). Wild boar prefer deciduous

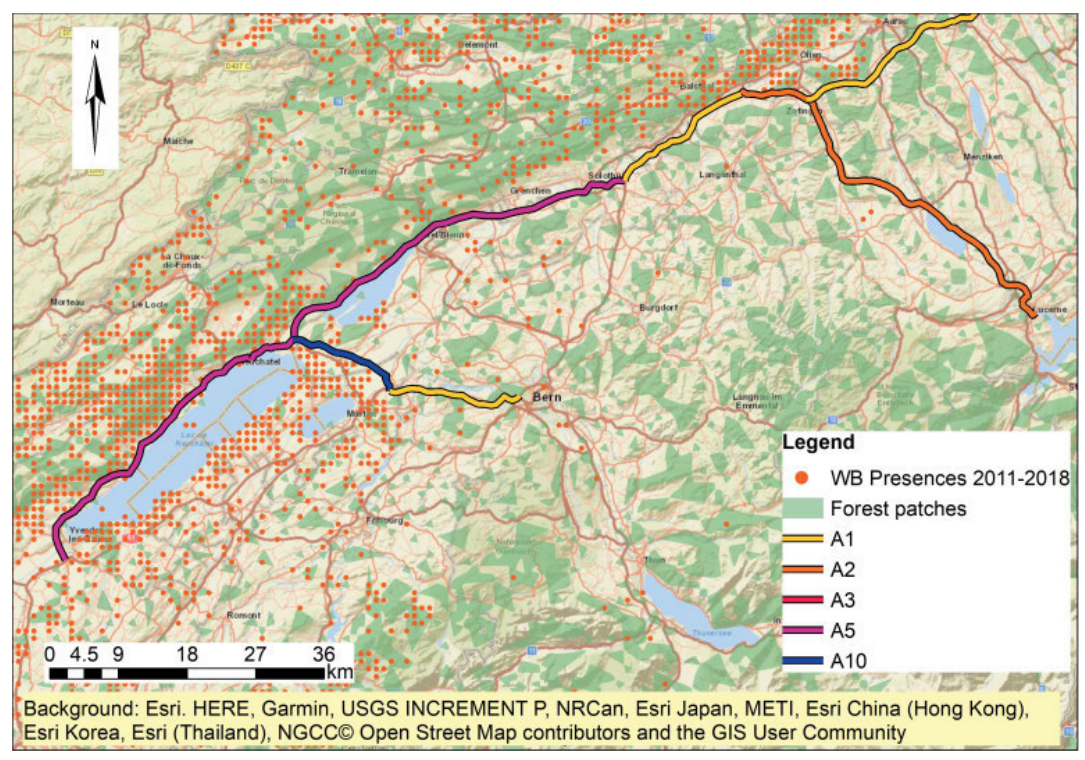

Figure 7: Natural and artificial barriers at the junction between Jura and the Swiss Plateau, and wild boar presences. A1-A10: Swiss national highways. This suggests that highway $A 5$ has been overcome by wild boars in the Neuchâtel area. However, highway A10 between Neuchâtel and Kerzers, highway A1 between Kerzers and Berne, and highway A1 between Luterbach and Birrfeld seem to be effective barriers. forests, where the fruits of the oak and beech trees provide a basic food resource, particularly during the cold season, over coniferous forests. ${ }^{42,29} \mathrm{~A}$ further barrier is highway A2 between Härkingen and Lucerne. Highway A3 between Zurich and Sargans is a barrier for wild boar colonizing Switzerland from the north. There the natural barriers of Walensee lake and Lake Zurich might also have prevented wild boar from colonizing Glarus and Schwyz. The migratory pressure onto Swiss cantons shielded by highways is expected to increase in the future: wildlife passages have to be built by law in order to increase the connectivity of the natural habitat.

The proportion of forest was found to be one of the main drivers of wild boar population expansion into unoccupied agroecosystems. ${ }^{40}$ This was attributed to the role forests play in providing wild boar with food resources and year-round protection, but also in constituting an important corridor facilitating wild boar population movement. In a study in the Geneva Basin, landscape fragmentation variables were the primary drivers of wild boar ranging patterns in a human-dominated agroecosystem with range size best explained by a model including landscape variables only. ${ }^{18}$ As mentioned above there is currently no viable population of wild boar in central Switzerland, despite the fact that there is some suitable habitat for this species. Hence, in addition to barriers, the remarkable patchiness of the predominantly coniferous forest together with a high fragmentation of landscape in general and the absence of hunting-free zones in the Oberaargau, Lucerne foreland, and Lucerne hinterland, which are regions in the Swiss Plateau, might also have limited the expansion of wild boar into suitable habitat. This is of relevance, since the piggeries in the canton of Lucerne are strongly connected with holdings in other cantons. ${ }^{51}$ There a potential contact between domestic pigs and wild boar could have severe consequences.

In the study presented here, the probability of wild boar occurrence across the study area was larger in summer than in winter. This is in line with the findings in the south of Belgium where the suitable habitat almost doubled in the growing season when compared to the hunting season. ${ }^{41}$ In Belgium this was explained by the cover and food provided by the agricultural area in the growing season. The computation of the mean probability of wild boar occurrence per land use class in Switzerland did not show any significant shift among the classes between summer and winter. This might be explained by the agricultural practice of yearly crop rotation on a small spatial scale. Accordingly, information on the type of crop grown, used as predictor variables in the Belgium study, was not available on the required scale in Switzerland. 


\section{Acknowledgements}

The authors would like to thank Rafael O. Wüest, Ph.D., from the Swiss Federal Research Institute WSL for always having a friendly ear for issues arising in the making of this article. This work was supported by the Swiss National Science Foundation (SNSF) NRP75, Project number 407540_167303.

\section{Appendix}

\section{Software tools and packages}

All modeling and evaluation were carried out in RStudio Version 1.2.1335 running $\mathrm{R} x 64$ 3.5.3. The following packages were used:

$\begin{array}{lll}\text { Ensemble modeling } & \text { Variable selection } & \text { Moran's I } \\ \text { library (biomod2) } & \text { library(AUCRF) } & \text { library (ape) } \\ \text { library (MASS) } & \text { library(tidyverse) } & \text { library (ncf) } \\ \text { library (mgcv) } & \text { library(rcompanion) } & \text { library (gam) } \\ \text { library (earth) } & \text { library (reshape) } & \\ \text { library(rpart) } & \\ \text { library (mda) } & \\ \text { library(Hisc) } & \\ \text { library (el071) } & \end{array}$

ArcGIS for Desktop 10.4.1 was used to prepare the input data to RStudio and to draw the maps.

\section{Predictor variables}

The predictor variables were fed from the following sources:

\section{Bioclimate}

Bioclimatic predictors (e.g., Bio 1-Bio 15 and SrelM in Table 1) were computed according to the formulas provided by the U.S. Geological Survey using grid data from the Federal Office of Meteorology and Climatology MeteoSwiss. ${ }^{37,38,44}$

\section{Topography}

Topographic predictors (e.g., slp in Table 1) were derived prior to this work from the Digital Elevation Model (swissALTI3D) of swisstopo. ${ }^{5,11}$

\section{Vegetation}

Seasonal vegetation predictors (e.g., $d \operatorname{deg} 0$ in Table 1) were computed according to the formula provided in related work using the grid data from the Federal Office of Meteorology and Climatology MeteoSwiss (cf. above). ${ }^{47}$ The forest mix rate of the National Forest Inventory (NFI) was computed prior to this work using multispectral aerial images and a Digital Terrain Model (DTM) developed from Airborne Laser Scanning (ALS) data. ${ }^{57}$

\section{Land fragmentation}

Land use (NOASO4 in Table 1) was computed based on the statistics of the Federal Statistical Office (BFS GEOSTAT). The forest mask was computed prior to this work based on Digital Surface Models (DSMs) from image-based point clouds of Airborne Digital Sensor (ADS) data. ${ }^{56}$

\section{Socio-economics}

The population density (STATPOP in Table 1) was computed based on the population and households statistics of the Federal Statistical Office (BFS).
Free-ranging wild boar

(Sus scrofa) in

Switzerland: casual

observations and

model-based projections

during open and closed

season for hunting

M.E. Vargas Amado et al. 
Free-ranging wild boar (Sus scrofa) in Switzerland: casua observations and model-based projections during open and closed season for hunting

M. E. Vargas Amado et al.

\section{Sanglier (Sus scrofa) en Suisse: observations occasionnelles et projections basées sur des modèles d'ouverture et fermeteure de chasse}

Le sanglier (Sus scrofa) est sensible à plusieurs maladies qui peuvent être transmises au cochon domestique. Afin d'estimer le risque potentiel de transmission, il est important d'identifier les zones occupées par le sanglier en Suisse ainsi que celles qu'il pourrait encore coloniser. De plus, cela implique également de pouvoir situer les secteurs où les élevages de cochons sont les plus abondant. Dans le présent travail, la distribution du sanglier a été projetée selon une grille à l'échelle de la Suisse à partir des présences confirmées en utilisant des méthodes statistiques, ceci en considérant la période d'ouverture de chasse d'une part et la période de fermeture d'autre part. Les probabilités de présence calculées ont été misent en relation avec la densité des porcheries dans les différentes zones agricoles. Les cartes résultant de cet exercice montrent comment le risque potentiel de transmission de maladies est distribué en Suisse. La base de données utilisée contenait des informations sur les sangliers tirés lors de la chasse, ainsi que des observations occasionnelles, rapportées à l'échelle de la coordonnée entre Septembre 2011 et Février 2018. Ces données ont étés obtenues de l'ensemble des 16 cantons maintenant un système de chasse à patente, plus Soleure (2017) et Zurich, et des données disponibles sur info fauna. La probabilité de trouver des sanglier est élevée ( $>0.7)$ dans le Jura, les vallées du sud des Alpes, la vallée du Rhône en aval de Martigny et la vallée du Rhin en aval de Bündner Herrschaft. Elle est modérée (0.5$0.7)$ pour le Plateau Suisse. Ces régions correspondent à peu près aux zones agricoles possédant les plus grandes densités de porcheries. Des secteurs offrant des conditions favorables toute l'année, mais encore inoccupés par le sanglier ont été trouvés dans les cantons de Berne, Obwald, Uri, Schwyz, Glaris et les Grisons. Sur l'ensemble de la zone d'étude, la probabilité de présence des sangliers était supérieur de $12 \%$ en dehors de la période de chasse. Les résultats ont été discutés en les comparant à des études similaires.

Mots-clés: Colonisation, adéquation de l'habitat, évaluation des risques, projection spatiale, distribution des espèces, Sus scrofa

\section{Cinghiale libero (Sus scrofa) in Svizzera: osservazioni casuali e pro- iezioni basata su modelli durante la stagione della caccia aperta e chiusa}

I cinghiali (i.e., Sus scrofa) sono sensibili a molte malattie che possono essere trasmesse ai suini domestici. Per la valutazione del rischio di trasmissione potenziale, è importante identificare le aree in cui i cinghiali vivono in Svizzera e quali possono ancora colonizzare. Si tratta inoltre di individuare le zone in cui la densità degli allevamenti di suini è molto densa. Nello studio qui presentato, la distribuzione dei cinghiali selvatici è stata proiettata sulla base di una griglia a livello svizzero a partire dalla presenza confermata utilizzando dei metodi statistici, considerando il periodo di apertura della caccia da una parte e di chiusura dall'altra. Le probabilità della presenza di cinghiali calcolate sono state messe in relazione con la densità degli allevamenti di suini nelle differenti zone agricole. Le carte che ne sono risultate mostrano come il rischio potenziale di trasmissione delle malattie sia distribuito in Svizzera. I dati utilizzati sulla presenza di cinghiali erano costituiti da dati provenienti dalla caccia e da osservazioni casuali registrate a livello di coordinate da settembre 2011 a febbraio 2018. Questi dati provenivano da tutti i 16 Cantoni svizzeri che mantengono un sistema di caccia con autorizzazione, più Soletta (per il 2017) e Zurigo, nonché da infofauna. La probabilità di avvistamento di cinghiali era alta $(>0,7)$ nel Giura, nelle valli delle Alpi meridionali, nella valle del Rodano sotto Martigny e nella valle del Reno sotto la Bündner Herrschaft (Signoria Grigionese); era moderata $(0,5-0,7)$ nell'Altipiano svizzero. Queste regioni si sovrappongono ampiamente alle zone agricole ad alta densità di allevamenti di suini. Nei Cantoni di Berna, Obvaldo, Uri, Svitto, Glarona e Grigioni sono state identificate zone di habitat adatte, ma attualmente non ancora popolate dai cinghiali. La probabilità della presenza di cinghiali in tutta l'area di studio, è aumentata del 12\% durante la stagione di chiusura della caccia. I risultati sono stati discussi e comparati a studi simili.

Parole chiavi: Colonizzazione, habitat adatto, valutazione del rischio, proiezione spaziale, distribuzione delle specie, Sus scrofa 


\section{References}

${ }^{1}$ Acevedo P, Croft S, Smith G, Vicente J: ENETwild modelling of wild boar distribution and abundance: initial model output based on hunting data and update of occurrencebased models. EFSA Supporting Publications 2019: 16(5): 25 .

2 Acevedo P, Quiros-Fernandez F, Casal J, Vicente J: Spatial distribution of wild boar population abundance: Basic information for spatial epidemiology and wildlife management. Ecological Indicators 2014: 36: 594-600.

${ }^{3}$ Alexander NS, Massei G, Wint W: The European Distribution of Sus Scrofa. Model Outputs from the Project Described within the Poster - Where are All the Boars? An Attempt to Gain a Continental Perspective. Journal of Open Health Data 2016: 4(1): e1.

${ }^{4}$ Araujo MB, Pearson RG, Thuiller W, Erhard M: Validation of species-climate impact models under climate change. Global Change Biology 2005: 11(9): 1504-1513.

${ }_{5}^{5}$ Baltensweiler A, Walthert L, Ginzler C, Sutter F, Purves RS, Hanewinkel M: Terrestrial laser scanning improves digital elevation models and topsoil $\mathrm{pH}$ modelling in regions with complex topography and dense vegetation. Environmental Modelling and Software 2017: 95: 13-21.

${ }^{6}$ Batista Linhares M, Belloy L, Origgi FC, Lechner I, Segner $H$, Ryser-Degiorgis MP: Investigating the role of free-ranging wild boar (Sus scrofa) in the re-emergence of enzootic pneumonia in domestic pig herds: a pathological, prevalence and risk-factor study. PLoS One 2015: 10(3): e0119060.

7 Bosch J, Mardones F, Perez A, de la Torre A, Munoz, MJ: A maximum entropy model for predicting wild boar distribution in Spain. Spanish Journal of Agricultural Research 2014: 12(4): 984-999.

8 Bosch J, Peris S, Fonseca C, Martinez-Aviles M, de la Torre A, Iglesias MI, Munoz MJ: Distribution, abundance and density of the wild boar on the Iberian Peninsula, based on the CORINE program and hunting statistics. Folia Zoologica 2012: 61(2): 138-151.

9 Breiman L: Random Forests. Machine Learning 2001: 45(1): 5-32.

${ }^{10}$ Calle ML, Urrea V, Boulesteix A-L, Malats N: AUC-RF: A New Strategy for Genomic Profiling with Random Forest. Human Heredity 2011: 72: 121-132.

11 Camathias L, Bergamini A, Küchler M, Stofer S, Baltensweiler A: High-resolution remote sensing data improves models of species richness. Applied Vegetation Science 2013: 16(4): 539-551.

12 Chenais E, Depner K, Guberti V, Dietze K, Viltrop A, Stahl $\mathrm{K}$ : Epidemiological considerations on African swine fever in Europe 2014-2018. Porcine Health Management 2019: 5: 6.

${ }^{13}$ Clopper CJ, Pearson ES: The Use of Confidence or Fiducial Limits Illustrated in the Case of the Binomial. Biometrika 1934: 26(4): 404-413.

${ }^{14}$ Cortes C, Vapnik VN: Support-Vector Networks. Machine Learning 1995: 20(3): 273-297.

${ }^{15}$ Crase B, Liedloff A, Vesk PA, Fukuda Y, Wintle BA: Incorporating spatial autocorrelation into species distribution models alters forecasts of climate-mediated range shifts. Global Change Biology 2014: 20(8): 2566-2579.
${ }_{16}$ Croft S, Smith G, Acevedo P, Vicente J: Wild boar in focus: initial model outputs of wild boar distribution based on occurrence data and identification of priority areas for data collection. EFSA Supporting Publications 2019: 16(1): 26.

17 Evans JS, Murphy MA, Holden ZA, Cushman SA: Predictive Species and Habitat Modeling in Landscape Ecology chap. Modeling Species Distribution and Change Using Random Forest. Springer, New York, NY, 2011: 139-159.

${ }^{18}$ Fattebert J, Baubet E, Slotow R, Fischer C: Landscape effects on wild boar home range size under contrasting harvest regimes in a human-dominated agro-ecosystem. European Journal of Wildlife Research 2017: 63(32), 1-9.

${ }^{19}$ Friedman JH: Multivariate Adaptive Regression Splines. The Annals of Statistics 1991: 19(1): 1-67.

20 Gallien L, Douzet R, Pratte S, Zimmermann NE, Thuiller W: Invasive species distribution models - how violating the equilibrium assumption can create new insights. Global Ecology and Biogeography 2012: 21(11): 1126-1136.

21 Gelfand SJ: Understanding the Impact of Heteroscedasticity on the Predictive Ability of Modern Regression Methods. Ph.D. thesis: Department of Statistical and Actuarial Science Faculty of Science, Simon Fraser University, 2015

22 Gini C: Variabilita e Mutabilita: Contributo allo studio delle distribuzioni e delle relazioni statistiche. Fascicolo 1: Introduzione - Indici di variabilita - Indici di mutabilita. Studi economico-giuridici pubblicati per cura della facolta di Giurisprudenza della R. Universita di Cagliari. Tipografia di Paolo Cuppini 1912.

23 Green RH: Sampling Design and Statistical Methods for Environmental Biologists. John Wiley, New York. 1979.

${ }^{24}$ Green SB: How Many Subjects Does It Take To Do A Regression Analysis. Multivariate Behavioral Research 1991: 26(3): 499-510.

${ }^{25}$ Guisan A, Thuiller W, Zimmermann NE: Habitat Suitability and Distribution Models: With Applications in R. Ecology, Biodiversity and Conservation. Cambridge University Press, Cambridge, United Kingdom. 2017.

${ }^{26}$ Hastie T, Tibshirani R, Buja A: Flexible Discriminant Analysis by Optimal Scoring. Journal of the American Statistical Association 1994: 89(428): 1255-1270.

27 Hastie TJ, Tibshirani RJ: Generalized Additive Models. Chapman \& Hall/CRC, Boca Raton, London, New York, Washington, D.C. 1st ed. 1990.

28 Hebeisen C, Fattebert J, Baubet E, Fischer C: Estimating wild boar (Sus scrofa) abundance and density using capture-resights in Canton of Geneva, Switzerland. European Journal of Wildlife Research 2008: 54: 391-401.

29 Herrero J, Irizar I, Laskurain NA, Garcia-Serrano A, GarciaGonzalez R: Fruits and roots: Wild boar foods during the cold season in the southwestern Pyrenees. Italian Journal of Zoology 2005: 72(1): 49-52.

30 Legendre P: Spatial Autocorrelation: Trouble or New Paradigm? Ecology 1993: 74(6): 1659-1673.

${ }^{31}$ Leuenberger R: Surveillance of wild boar in Switzerland: prevalence of infections relevant to domestic pigs. Ph.D. thesis: Universität Basel, 2004.

32 Maron ME: Automatic Indexing: An Experimental Inquiry Journal of the ACM 1961: 8(3): 404-417.

${ }^{33}$ McCulloch WS, Pitts W: A logical calculus of the ideas immanent in nervous activity. Bulletin of Mathematical Biophysics 1943: 5(4): 115-133.
Free-ranging wild boar (Sus scrofa) in Switzerland: casual observations and model-based projections during open and closed season for hunting

M.E. Vargas Amado et al. 
Free-ranging wild boar (Sus scrofa) in Switzerland: casual observations and model-based projections during open and closed season for hunting

M.E. Vargas Amado et al.
${ }^{34}$ Meier RK: Investigations of health and abundance of free-ranging wild boar (Sus scrofa) in Switzerland in a European context. Ph.D. thesis: Vetsuisse Faculty, University of Bern, 2015.

35 Meier RK, Ryser-Degiorgis M-P: Wild boar and infectious diseases: evaluation of the current risk to human and domestic animal health in Switzerland: A review. Schweiz Arch Tierheilkd 2018: 160(7-8): 443-460.

${ }^{36}$ Merli E, Meriggi A: Using harvest data to predict habitat-population relationship of the wild boar Sus scrofa in Northern Italy. Acta Theriologica 2006: 51(4): 383-394.

37 MeteoSwiss: Documentation of Grid-Data Products. Monthly and Yearly Mean Temperature: TabsM and TabsY. March 2016: v1.4. https://www.meteoswiss.admin.ch/content/dam/meteoswiss/de/service-und-publikationen/produkt/raeumliche-daten-temperatur/doc/ProdDoc_TabsM. pdf (accessed 14.01.2020)

38 MeteoSwiss: Documentation of Grid-Data Products. Monthly and Yearly Precipitation: RhiresM and RhiresY March 2016: v1.0. https://www.meteoswiss.admin.ch/content/dam/meteoswiss/de/service-und-publikationen/produkt/raeumliche-daten-niederschlag/doc/ProdDoc RhiresM.pdf (accessed 14.01.2020)

39 Moran PAP: Notes on Continuous Stochastic Phenomena. Biometrika 1950: 37(1/2): 17-23.

40 Morelle K, Fattebert J, Mengal C, Lejeune P: Invading or recolonizing? Patterns and drivers of wild boar population expansion into Belgian agroecosystems. Agriculture Ecosystems \& Environment 2016: 222: 267-275.

${ }^{41}$ Morelle K, Lejeune P: Seasonal variations of wild boar Sus scrofa distribution in agricultural landscapes: a species distribution modelling approach. European Journal of Wildlife Research 2015: 61: 45-56.

42 Moretti M: Saisonale Raumverteilung, Habitatnutzung und Standortwahl des Wildschweins Sus scrofa (L.) in einem Berggebiet auf der Alpensüdseite der Schweiz (Malcantone, Tessin). Diploma thesis: Zoologisches Institut der Universität Zürich, Abteilung Oekologie, 1991.

43 Nelder JA, Wedderburn RWM: Generalized linear models. Journal of the Royal Statistical Society. Series A (General) 1972: 135(3): 370-384.

44 O'Donnell MS, Ignizio DA: Bioclimatic Predictors for Supporting Ecological Applications in the Conterminous United States. Data Series 691. U.S. Geological Survey, Reston, Virginia, 2012 https://pubs.usgs.gov/ds/691/ds691.pdf (accessed 14.01.2020)

45 Phillips SJ, Dudik M, Elith J, Graham CH, Lehmann A, Leathwick J, Ferrier S: Sample selection bias and presence-only distribution models: implications for background and pseudo-absence data. Ecological Applications 2009: 19(1): 181-197.

46 Pittiglio C, Khomenko S, Beltran-Alcrudo D: Wild boar mapping using population-density statistics: From polygons to high resolution raster maps. PLOS ONE 2018: 13(5): 1-19.

47 Prentice I, Cramer W, Harrison S, Leemans R, Monserud R, Solomon A: Special Paper: A Global Biome Model Based on Plant Physiology and Dominance, Soil Properties and Climate. Journal of Biogeography 1992: 19(2): 117-134.

48 Provost F, Fawcett T: Robust Classification for Imprecise Environments. Machine Learning 2001: 42(3): 203-31.

49 Renner IW, Warton DI: Equivalence of MAXENT and Poisson Point Process Models for Species Distribution Modeling in Ecology. Biometrics 2013: 69(1): 274-281.
50 Sinha P, Gaughan AE, Stevens FR, Nieves JJ, Sorichetta A, Tatem AJ: Assessing the spatial sensitivity of a random forest model: Application in gridded population modeling. Computers, Environment and Urban Systems 2019: 75: 132-145.

${ }^{51}$ Sterchi M, Faverjon C, Sarasua C, Vargas ME, Berezowsk J, Bernstein A, Grütter R, Nathues $H$ : The pig transport network in Switzerland: Structure, patterns, and implications for the transmission of infectious diseases between animal holdings. PLOS ONE 2019: 14(5): 1-20.

52 Suter S, Stoller S, Sigrist B: Prävention von Wildschweinschäden in der Landwirtschaft und Management von Wildschweinen in Schutzgebieten. Schlussbericht. Tech. rep., Zürcher Hochschule für Angewandte Wissenschaften ZHAW, Institut für Umwelt und Natürliche Ressourcen IUNR, Forschungsgruppe Wildtiermanagement WILMA, Schloss, CH-8820 Wädenswil. 2018.

53 Swets JA: Measuring the accuracy of diagnostic systems. Science 1988: 240(4857): 1285-1293.

${ }^{54}$ Swiss Confederation. Federal Department of Foreign Affairs. Geography - Facts and Figures. Bern, CH https:// www.eda.admin.ch/aboutswitzerland/en/home/umwelt/ geografie/geografie---fakten-und-zahlen.html (accessed 28.03.2020)

55 Swiss Confederation. Federal Office of Meteorology and Climatology MeteoSwiss. The Climate of Switzerland. Bern, CH https://www.meteoswiss.admin.ch/home/climate/the-climate-of-switzerland.html (accessed 28.03.2020).

56 Waser LT, Fischer C, Wang Z, Ginzler C: Wall-to-Wall Forest Mapping Based on Digital Surface Models from Image-Based Point Clouds anda NFI Forest Definition. Forests 2015: 6(12): 4510-4528.

57 Waser LT, Ginzler C, Rehush N: Wall-to-Wall Tree Type Mapping from Countrywide Airborne Remote Sensing Surveys. Remote Sensing 2017: 9(8), 766 (24 pp.)

58 WLS.CH. WildLife Solutions. Wild Boar. Lossy, $\mathrm{CH}$ https://wls.ch/sanglier/ (accessed 28.03.2020).

59 Wu N, Abril C, Hinic V, Brodard I, Thür B, Fattebert J, Hüssy D, Ryser-Degiorgis M-P: Free-ranging wild boar: a disease threat to domestic pigs in Switzerland? Journal of Wildlife Diseases 2011: 47(4): 868-879.

60 Wu N, Abril C, Thomann A, Grosclaude E, Doherr MG, Boujon P, Ryser-Degiorgis M-P: Risk factors for contacts between wild boar and outdoor pigs in Switzerland and investigations on potential Brucella suis spill-over. BMC Veterinary Research 2012: 8(1): 116-128.

\section{Corresponding author}

R. Grütter, DVM, MBA

Swiss Federal Research Institute WSL

Zürcherstrasse 111

8903 Birmensdorf

Switzerland

Phone +41447392509

E-Mail: rolf.gruetter@wsl.ch 